
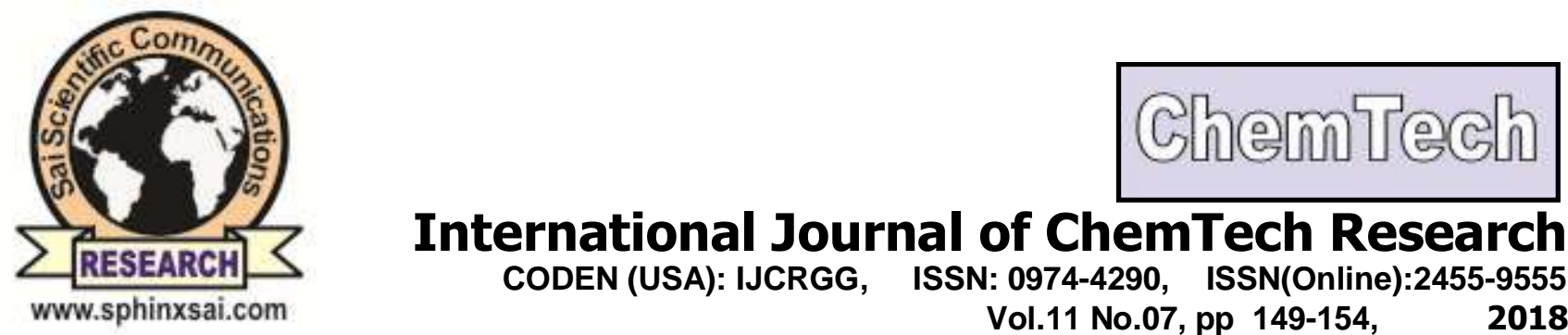

\title{
Ethno Medicine Therapy for Oral Health Problem in Hinterland
}

\author{
Ristya Widi Endah Yani ${ }^{1 \star}$, \\ I Dewa Ayu Ratna Dewanti ${ }^{1}$, Muhammad Anshari ${ }^{2}$ \\ ${ }^{1}$ Faculty of Dentistry University of Jember, Indonesia \\ ${ }^{2}$ Faculty of Public Health Muhammadiyah University, Banjarmasin Indonesia
}

\begin{abstract}
The focus was on a study of babalian in healing oral hygiene problem. Ethnography research with semi-structured depth interview was done for two shamans (balian) who live in Paramasan Bawah village. The interview was done to investigate the factors of having the disease, the history of medicinal plants, the way of healing the disease by processing the plants, and how to get the knowledge hereditarily. Medicinal plant specimens were collected, identified and kept at Plant Conservation Center which located in Botanical Garden (LIPI). The collecting and the analyzing data were done based on developmental research sequences by James Spradley. Babalian ethno medicine is belonging to the people's personalize belief while the ethno medicine therapy for dental and oral health problem consists of basambur ritual and herb (pelungsur). It was found that 8 out of 13 species families of pelungsur commonly used for treating dental and oral health problem. Basambur ritual refers to the local wisdom which comes from their philosophy and belief system of their tribes. It also can be related to the belief system induction in predicting positive perception toward thinking system. The last step of basambur could become the positive biology response either. Meanwhile, herb (pelungsur) was used as traditional medicine and the effect was able to be increased through basambur ritual.
\end{abstract}

Key words : Dental and oral health problem, dental caries, ethno medicine.

\section{Introduction}

Statistics Indonesia recorded that in 2010, Indonesian population has 1.340 ethnics. Every ethnic has their own characteristics in deciding the way to manage their lives, dealing with the interaction to their environment social and ethno medicine is included. Indonesia belongs to the mega biodiversity and it places $1,3 \%$ of wide surface of earth, yet $17 \%$ from all species in all around the world. Moreover, there are so many medical plants that have big potential as raw material of medicine. Most of them can be found either inside or outside of the Indonesian forests and have different characteristic for each. Furthermore, this kind of information is so important to the medicine development because there are many plant extracts found for modern medicine through this approach. ${ }^{1}$

Ristya Widi Endah Yani et al /International Journal of ChemTech Research, 2018,11(07): 149-154.

DOI= http://dx.doi.org/10.20902/IJCTR.2018.110718 
Dayak Paramasan Meratus Ethnic lives at Meratus Mountains, Paramasan sub-district, Banjar District, South Kalimantan, Indonesia. It was $168 \mathrm{~km}$ from Martapura (The Capital City from Banjar) and it is needed to pass two districts, Tapin and Hulu Sungai Selatan, to get there. Moreover, Paramasan is settled as very primitive area by The Local Government because of the difficult access area to reach and some considerations (SK Banjar Regent No. 033 in 2009). In addition, most of the people are farmers and gold digger, and in about $90 \%$ of them are illiteracy. It is getting worse if we are looking at the fact that the majority of them are categorized as living under the poverty. On the other hand, its width is $560,85 \mathrm{~km}^{2}$ and it is located in Maratus Mountains with 3.592 people with the population density is 6 people $/ \mathrm{km}$. It is divided into 4 villages, Paramasan Bawah village, Paramasan Atas village, Remo village and Angkipih village. ${ }^{2}$

The local Government of Banjar district had built a community health care since 2008 and it is located in Paramasan village. Yet, it is still only for the obstetrician and the general ones. The less facility of the health care is not able to change the role of ethno medicine babalian. It can be said that they still have strong belief for having babalian, a traditional medicine, instead of seeing the doctor to treat their disease.

Babalian ethno medicine is such an interesting phenomenon topic to be studied about. The background of the problem is how babalian ethno medicine can heal various diseases including dental and oral health problem. This research is started with finding the further information about babalian ethno medicine which involves philosophy and the methodology of treating the disease. They are focused on the ritual and the use of medical plant (herbal) to heal the dental and oral health problem.

\section{Materials and Method}

This study is a qualitative research with ethnography approach. Data collection method is done with semi-structured depth interview and active participation. The researcher is directly getting involved in curing the disease. The key respondent is balian (the shaman), namely Usron who comes from Munggu Lahung village and another balian, Uliansyah, is from Paramasan Bawah village, Paramasan district. The collecting and analyzing the data are done with developmental research sequences methodology by James Spradley.

The research in Paramasan Bawah village was done in January 2017 until July 2017. The researcher did the observation and the semi-structured depth interview to balian in giving the treatment. It was done to get the description about following information, such as: disease etiology according to babalian ethno medicine, how the process of the treatment is done, how the medical plants play a role in the treatment, the estimation of balian about the origin of applying the medical plants and how the knowledge about it could be obtained and inherited. The recording of the interview result is gotten with the respondents' permission. Moreover, the medical plants for treating the dental and oral health problem was collected then identified by Plant Conservation Center at Botanical Garden of Purwodadi-LIPI Lawang, East Java.

\section{Results}

\section{Disease and treatment concept}

Babalian ethno medicine explains that disease happens because of the relationship between human and the environment is imbalanced. If this disharmony-relation happens, human will accept such poison from ruh (the ancient soul) as the reminder, anger or even the punishment over his own attitude.

"It happens because of their own attitude that breaks the rule, so, ruh will give him poison and he will get sick of it...." (Balian Uliansyah)

The health concept above refers to the importance of every individual to have attitude which is "Aruh" with the entire creature in this universe. Aruh comes from the word " $a$ " and "ruh" which means "(a)" agreement and "(ruh)" all the souls, defines that we need to have good attitude in our daily lives, our lives need to "aruh" with full of heart, whole body, family, people around, the environment, ancient soul, and others, especially to the almighty God.

"The ancestors taught us to have an "aruh" life in order to be safe and happy." (Balian Uliansyah). 
Balian religion philosophy believes that the environment has a soul (spirit), so does the stone, mountain, river, plant, fire, etc.

"All the things in this universe have soul of each. There is stone soul, water soul, mountain soul, forest soul, etc." (Balian Uliansyah)

"God creates devil to tempt the human and the devil soul can disturb the human and bring them various disease." (Balian Uliansyah).

Furthermore, healing the disease can be done by one of the following ways, such as (1) The soul who releases the disease take the poison back and it can be happened by giving apology and "sesaji" (ritual offerings) through a healing ceremony. It is done if the patient has already realized what his fault was. (2) The second, there is natural energize that has capability to neutralize the soul disturbance. In line with this, certain medical plant (pelungsur)is believed has this kind of energy needed. (3) The last, God's Help (swara). Even though Balian believes on the existing ancestor soul, Goddess, and natural ruh, among all of these, they also have the same strong believe to the most powerful that creates the entire universe. Besides, they also believe that as the God's permission, all the poison of souls will be disappear.

Babalian ethno medicine dealing with dental and oral health problem consist of two treatments, basambur ritual and ramuan (herbs) of medical plants. Medical plant herbs are obtained from wild plants at the forests. It is usually called pelungsur that they believe have natural power to absorb or neutralize the disturbance poison. Meanwhile, basambur ritual belongs to the short-term ritual of giving mamangan (mantra) to the patient and the herbs given.

"First of all, spouting the water or fluttering with black fabric and giving the mantra for the severe disease, giving pelungsur, but if the disease is not healing yet, it is necessary to have babalian ritual to beg to God." (Balian Usron).

\section{The Role of Medical Plants as the Treatment Component}

Based on babalian philosophy, God creates plants is for food and detox as well, that is able to neutralize all the natural disturbances on human's body. This important function places the plants as the central system of babalian ethno medicine. Moreover, medical plants have the capability of defeating the toxin that is released by natural souls, so, they can be removed and disappeared.

"Pelungsur has destiny to have the ability in removing all the poison that was released by the natural soul." (Balian Usron)

The process of picking the medical plants from forests need to take the consideration of certain time, in which the best time to pick the plants, is around 12.30 p.m. until 1 p.m. The previous balian will spell mantra before picking the plants. It is done to ask God's permission to pick the plants for the good thing, it is healing the disease. In addition, stating the (mamang) mantra is dedicated to Suwara and using Banjar arkais language (Anient banjar language)

\section{Disease Treatment}

Dayak Pramasan ethnic is well known toothache as tooth holes, painful, and inflammation. Meanwhile, oral health problem is familiar as mouth ulcer, which is actually belonging to the inflammation of oral mucosa. Dental and oral health problem is usually healed by medical plant around the houses. The plant sometimes is needed only one kind of plant but sometimes using several mixed plants, yet it depends on how severe the patient is.

Balian do the treatments consisting of two steps, preparing pelungsur and basambur ritual. (1) Balian will give one or more herbs pelungsur. In some cases, balian boils some of medical plants and the patient will be given them in mental container/pottery. After that, strained the boiling water and medical plants and waiting until it is cool. If it is done, balian will give mantra as the praying to God. (2) Basambur or batapung tawar is a simple ritual through casting mamang (mantra) to the patient. Balian will cast mamang-mamang with flattering the black fabric or yellow ones to the patient and blowing either touching the part of sickness. Besides, 
basambur is also can be done with casting mamang to the water as soaking pelungsur if the patient is far or cannot come to balian house.

\section{Discussion}

\section{Basambur as Coping Mechanism}

Babalian ethno medicine describes disease and the causes as personalize belief. Foster and Anderson (1986) explains that personalize assume the illness is causing of the interventions from active agent, which could be supernatural thing (spirit, god), non-human thing (ghost, ancestor soul, ghouls) even human itself (witch or clairvoyant).

If Dayak people get sick, they think that it is life event which responses individually as the situational meaning. Moreover, it also can be said as the certain condition in which the causing of his suffering (depressed physically and mentally) will be able to get the negative perception. Thus, situational meaning of his will become conflict with global meaning and at the end it could be make him distress. ${ }^{3,4}$ Distress can encumber psychology endurance and it will end with depress increasing. In line with this, biology response that has existence as distress response, through HPA line (Hipothalamus-Pituitary-Adrenal) of the increasing cortisol level over physiologist level, ${ }^{5,6,7}$ affect the suppression through immunity system. ${ }^{7}$ The increasing of neutrophil and the decreasing NK cell, lymphocytes $\mathrm{T}$ and $\mathrm{B}$, helper cell, and $\mathrm{T}$ depression cell is belonging to the decreasing of $\mathrm{NK}$ cell and lymphocytes response towards mitogen stimulation as well. ${ }^{8}$ Even worse, this condition can make the treatment process of the illness is difficult and being obstacle, especially for the infection case. ${ }^{4}$

Basambur ritual denotes local cultural wisdom which is being collective mindset of Dayak ethnics. Giving herbs (pelungsur) while basambur ceremony means that to help a sick Dayak people to have a process namely coping in which the cognitive process of thinking system zone. Furthermore, the intervention of collective mindset aroused through basambur ritual will strengthen his belief system. On the other hand, the output is acceptance, submissiveness and depth realizing. It is the most basic and adaptive process because of the changing is belonging to belief, value, and rule which tends to be effective and powerful to create attitude and behavior either biologist effect. ${ }^{4}$ The end result of coping mechanism is the perception response shifting from distress to eustress, which means the positive stress and could be seen by biologist response (stress response) of improving physiologist cortisol level and immunity system as well. ${ }^{4,8}$

In addition, medical plants that is usually used for dental caries are Gudai (Cajamus cajan), Hiring, Sungkai (Scleria laevis Willd), Kamandrah (Cratoxylum tignum), Pulantan. (Alstonia angustiloba). According to research finding towards the medical plants are obtained various potential advantages such as: Immunomodulatory. ${ }^{9}$ Anti cancer activity. ${ }^{10}$ Antipyretic dan anti-inflammatory. ${ }^{11}$ Sedative, analgesic and antibacterial activity. ${ }^{12}$

Indeed, medical plants to heal the pain and swelling are: daun kembang ruku (Ocimum sp), daun pulut tai (Wedelia biflora), akar gelinggang (Senna alata), daun racun ayam (Brucea javanica), Pulantan (Alstonia angustiloba), kulit batang badarah pinang (Myristica maxima), akar ulin (Eusideroxylon zwageri). Likewise, based on the research findings to those medical plants, there are some benefits such as to obstacle the fungicidal, anti-bacteria activity mycobacterium tuberculosis, M.pyogenes, S.aureus, E.coli). ${ }^{13}$ Antioxidant properties and antimicrobial activities, ${ }^{14}$ wound-healing, anti-inflammatory. ${ }^{15}$ antitumor efficacy lies in induction of apoptosis and decreasing cell proliferation. ${ }^{16}$ Free radical scavengingactivity. ${ }^{17}$

Further, medical plants that is used to heal oral mucosa are: akar kamandrah (Cratoxylum tignum), kulit batang badarah pinang (Myristica maxima), kulit batang jintungan (Bischofsia javanica), kulit kayu miwai (Saccopetalum houfeedi). The previous study found that there are some benefits of these plants such as treatment of ulcers, sores, boils, antiulcer, anthelmintic and ant dysenteric activities. ${ }^{18}$ 
Tables : This following table is the list of usual medical plant that is used for treating the dental and oral health problem.

\begin{tabular}{|c|c|c|c|c|}
\hline NO & Local Name & Species & Familia & Benefits and Applying \\
\hline 1 & Ulin & $\begin{array}{l}\text { Eusideroxylon } \\
\text { zwageri }\end{array}$ & Lauraceae & $\begin{array}{l}\text { Roots; boiling for toothache; as } \\
\text { mouthwash }\end{array}$ \\
\hline 2 & Racun ayam & Brucea javanica & Simaroubaceae & Leaves; toothache; squeezed it \\
\hline 3 & Gelinggang & Senna alata & Leguminosae & $\begin{array}{l}\text { Roots; toothache; boiled and } \\
\text { gargled }\end{array}$ \\
\hline 4 & Gudai & Cajamus cajan & Leguminosae & $\begin{array}{l}\text { Roots; folium; toothache; grinded } \\
\text { and put in cavity tooth }\end{array}$ \\
\hline 5 & Hiring & Scleria laevis Willd & Cyperaceae & $\begin{array}{l}\text { Tuber root; dental caries; chewed, } \\
\text { put in cavity tooth }\end{array}$ \\
\hline 6 & Sungkai & Peronema canescens & Verbenaceae & $\begin{array}{l}\text { Cortex's sap ; toothache; put it in } \\
\text { cavity tooth }\end{array}$ \\
\hline 7 & Pulut Tai & Wedelia biflora & Compositae & $\begin{array}{l}\text { Young leaves; toothache; } \\
\text { squeezed; put it in the pain tooth }\end{array}$ \\
\hline 8 & Kamandrah & Cratoxylum tignum & Euphorbiaceae & $\begin{array}{l}\text { Roots; tootache and mouth ulcer; } \\
\text { scrapped and put in cavity tooth }\end{array}$ \\
\hline 9 & Kambang Ruku & Ocimum sp. & Lamiaceae & $\begin{array}{l}\text { Leaves; toothache; squeezed and } \\
\text { put it in the causing pain }\end{array}$ \\
\hline 10 & Badarah Pinang & Myristica maxima & Myristicaceae & $\begin{array}{l}\text { cortex; toothache and oral } \\
\text { inflammation; boiled }\end{array}$ \\
\hline 11 & Jintungan & Bischofsia javanica & Euphorbiaceae & $\begin{array}{l}\text { cortex; mouth ulcer and chapped } \\
\text { lips; crapped and swapped }\end{array}$ \\
\hline 12 & Miwai & $\begin{array}{l}\text { Saccopetalum } \\
\text { houfeedi }\end{array}$ & Annonaceae & $\begin{array}{l}\text { Cortex lignum; mouth ulcer and } \\
\text { oral inflammation ; boiled and } \\
\text { drank }\end{array}$ \\
\hline 13 & Pulantan & Alstonia angustiloba & Apocynaceae & $\begin{array}{l}\text { Tree's sap; toothache; put it in the } \\
\text { causing pain }\end{array}$ \\
\hline
\end{tabular}

\section{Conclusion}

Babalian ethno medicine is derived from belief system of Dayak Paramasan Meratus Mountains and it inspires treatment technique of theirs. There are two steps of the ethno medicine for dental and oral health problem, pelungsur and basambur. Pelungsur (herbs) refers to traditional medicine and its efficacy is being improved with basambur ritual through positive perception of response mechanism that stimulates positive physiologist response.

\section{References}

1. $\quad$ Hendri, A.H. Sensus Penduduk 2010. Badan Pusat Statistik. 2011.

2. Anshari M., Tri Martiana Taat Putra S., Dyson L. Ethnomedicine of dayak paramasan ethnic in the Meratus Mountains (part-1), the medicinal plants for diarrhea and respiratory disorder, J. appl. environ. biol. sci., 2015, 5: 139-147.

3. Park, C., Edmondson, D., \& Mills, M. Religious worldviews and stressfull encounters. New York, Springer, 2010, 125-130.

4. Anshari M. Disertasi: konsep ritual baharagu dalam mempengaruhi respons persepsi dan biologik pada praktek etnomedisin dayak paramasan meratus, universitas airlangga, surabaya, 2016, 204-263.

5. Boonen, E. Reduced cortisol metabolism during critical illness. Nursing Engl Journal medicine, 2013, 477-1488.

6. Ellenbogen, M. A. Stress and selective attention: The interplay of mood, cortisol levels and emotional information proccessing. Physiology, 2002, 723-732. 
7. Ebrecht, S. R., \& Kunt, W. Cortisol responses to mild psychological stress are inversely associated with pro inflammatory cytokine. Brain, Behavior and Immunity, 2003, 373-383.

8. Ader, R. Psychoneuroimunoly: interactions between the nervus system and he immune system. The Lancet, 1995, 99-101.

9. Feng, L. A combination of alkaloids and triterpenes of alstonia scholaris (linn.) r. br. leaves enhances immunomodulatory activity in c57b1/6 mice and induces apoptosis in the a549 cell line. J. Molecules, 2013, 18: 13920-13939.

10. Lu L., Jian-Xin C., Yuan-Cheng, Y., \& Sheng-Ping X. Progress of pharmacological studies on alkaloids from apocynaceae. Journal of Asian Natural Products Research, 2013, 15(2): 166-184.

11. Yani,A.P., \& Putranto, A.M. H. Examination of the sungkai's young leaf extract (peronema canescens) as an antipiretic, immunity, antiplasmodium and teratogenity in mice (mus.muculus). International Journal of Science and Engineering, 2014, 7: 30-34.

12. Pal, D., Mishra, P. Sachan,N., \& Ghosh,A.K. Biological activities and medicinal properties of Cajanus cajan (L) Millsp. J Adv Pharm Technol Res, 2011, 2: 207-214.

13. Padma, V., Suman, K., Setyawati, S. Bioactive botanicals from basil (ocimum sp.). Journal of Scientific and Industrial Research, 1999, 58: 332-338.

14. D. Biswas, G. P. Yoganandam A. Dey And L. Deb. Evaluation of antimicrobial and wound healing potentials of ethanol extract of wedelia biflora linn d.c. leaves. Indian Journal of Pharmaceutical Sciences, 2013, 75:156-161.

15. Hennebelle, T. Weniger,B. Joseph,H.Sahpaz,S. Senna alata, Fitoterapia 80, 2009, 385-393.

16. Chen,M., Chen,R., Wang,S., Tan,W., Hu,Y., Peng,X., \& Wang, Y. Chemical components, pharmacological properties, and nanoparticulate delivery systems of Brucea javanica. Int J Nanomedicine, 2013, 8:85-92.

17. Othman, M.A., Sivasothy,Y., Looi, C.Y., Ablat,A., Mohamad,J., Litaudon,M., \& Awan, K. Acylphenols and dimeric acylphenols from myristica maxima warb. Fitoterapia, 2016, 80: 385-393.

18. M. Rkhan. Anti-microbial activity of Bidens pilosa, Bischofia javanica, Elmerillia papuana and Sigesbekia orientalis. Fitoterapia, 2011, 72: 662-665. 